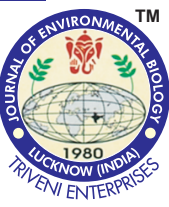

\title{
Detection of ribavirin in environmental and biological samples via optical chemical sensor
}

\section{Authors Info \\ S. Wei', L. Shao ${ }^{3}$, S. Zhang ${ }^{1}$, H. Cheng $^{2 *}$ and W. Liang \\ 'School of Food \& Pharmaceutical Engineering, College of Environmental and Chemical Engineering, Zhaoqing University, Zhaoqing, 526 061, P.R. China \\ ${ }^{2}$ Guangxi Key Laboratory of Green Processing of Sugar Resources, College of Biological and chemical engineering, Guangxi University of science and technology, Liuzhou, Guangxi, 545 006, P. R. China \\ ${ }^{3}$ School of Environmental Science and Engineering, Hebei University of Science and Technology, Shijiazhuang, 050 018, P.R. China \\ ${ }^{*}$ Corresponding Author Email : hc0229@live.com}

Edited by

Dr. Shoulian Wei

Reviewed by

Dr. Liya Niu

Dr Ravindra Khaiwal

\begin{abstract}
Aim: This study was conducted to determine the Ribavirin in Environmental and Biological Samples via Optical Chemical Sensor.

Methodology: In this paper, a new magnetic metal-organic framework $\mathrm{Fe}_{3} \mathrm{O}_{4} @ \mathrm{Fe}-\mathrm{ASB}$ was synthesized with nano- $\mathrm{Fe}_{3} \mathrm{O}_{4}$ as metal center and a new Schiff base, which was synthesized from quinoline-2formaldehyde and $\beta$-mercaptoethylamine, as ligand, This $\mathrm{Fe}_{3} \mathrm{O}_{4} @ \mathrm{Fe}-\mathrm{ASB}$ was characterized by FITR, SEM and XRD. Its enzyme-like activity was characterized by the chromogenic substrate $\left(\mathrm{H}_{2} \mathrm{O}_{2}\right.$ and TMB) and verified based on the Michaelis-Menten equation.
\end{abstract}

Results: The results showed that the synthesis of $\mathrm{Fe}_{3} \mathrm{O}_{4} @ \mathrm{Fe}-\mathrm{ASB}$ was successful and it exhibited excellent enzyme-like activity. The $\mathrm{Fe}_{3} \mathrm{O}_{4} @ \mathrm{Fe}-\mathrm{ASB}$ was successfully used for the detection of ribavirin in water samples as catalytic material. It showed good stability, accuracy and precision. This testing method features a graph, which plots concentration ( $c_{\text {ribavinin }}$ ) on the $x$-axis and absorption $A$ on the $y$-axis to create a linear equation. It shows a good linear relation ranging from $1 \times 10^{-4} \mathrm{~mol} \mathrm{I}^{-1}$ to $1 \times 10^{-6} \mathrm{~mol} \mathrm{I}^{-1}$, with a limit detection of $2 \times 10^{-7} \mathrm{moll}^{-1}$. The mean recovery rates for spike recovery experiments varied from $92.0 \%$ to $109 \%$.
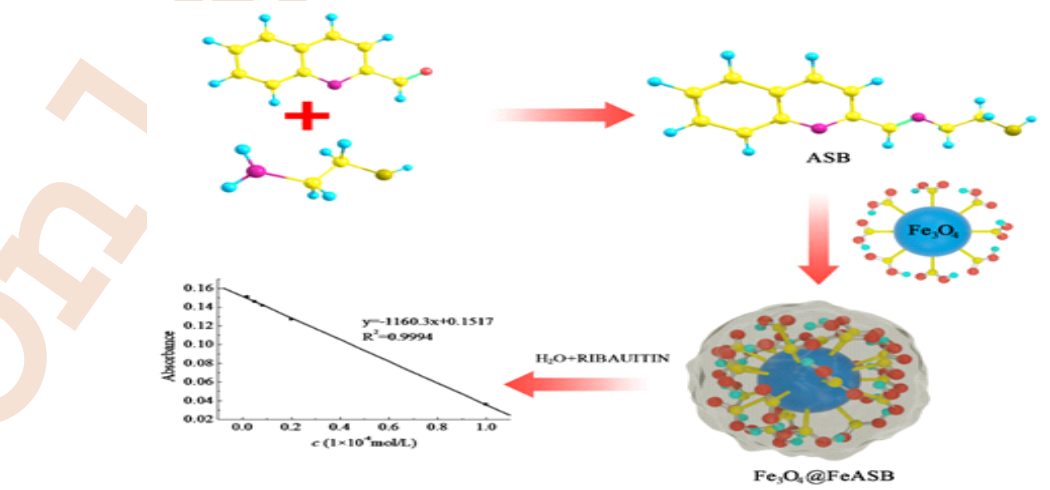

Interpretation: A new Schiff base was synthesized from quinoline-2-formaldehyde and $\beta$ mercaptoethylamine. Then, a new magnetic metal-organic framework $\mathrm{Fe}_{3} \mathrm{O}_{4} @ \mathrm{Fe}-\mathrm{ASB}$ was synthesized by it with nano- $\mathrm{Fe}_{3} \mathrm{O}_{4}$ as the metal center. The $\mathrm{Fe}_{3} \mathrm{O}_{4} @ \mathrm{Fe}-\mathrm{ASB}$ was successfully used for the detection of ribavirin in water samples as catalytic material. It showed good stability, accuracy and precision.

Key words : Catalyst, Feed, Optical chemical sensor, Ribavirin

Citation: Wei, S. , L. Shao, S. Zhang, H. Cheng and W. Liang: Detection of ribavirin in environmental and biological samples via optical chemical sensor. J. Environ. Biol., 40, 497-508(2019). 


\section{Introduction}

Ribavirin, also known as virazole, RTCA and tribavirin, is a broad-spectrum antiviral drug (Wenying, 2010; Shaikh et al., 2017). Researchers home and abroad have analyzed its risks and clinical data indicate that ribavirin has side effects (Hua et al., 2006). Serious side effects include dissolution anemia, genotoxicity, reproductive toxicity, carcinogenicity and teratogenicity (Jingxian et al., 2013; Cho, 2017; Ayaz et al., 2018). As ribavirin is only used for human in clinic and lacks scientific basis and pharmacological research on animals. On March 22 2006 the FDA published a final rule prohibiting the extra label use of adamantane and neuraminidase inhibitor classes of antiviral drugs in animals. As ribavirin is only approved for treating humans, it lacks scientific evidence and pharmacological studies on animals (Lei et al., 2013; Wahab and Adzmi, 2017; Jamal et al., 2018). There are few methods for the detection of ribavirin residues inside animals or in animal feeds, so it is necessary to find a rapid, simple and effective method for the detection of ribavirin.

At present, ribavirin is mainly detected by HPLC, UV spectrophotometry, capillary electrophoresis and HPLC-MS/MS (Xiaozhen, 2011; Wanzhen et al., 2005; Fei and Li, 2011; Azizan et al., 2017; Biswas, 2018). However, these methods require significant time for analysis, expensive instruments and skilled operators. Such high requirements hinder their further application.

Several reports are available on $\mathrm{H}_{2} \mathrm{O}_{2}$ as catalysis, both at home and abroad, including natural HRP, nano hydrogen peroxidase and metal-organic framework (Haijun et al., 2007; Xiufang, 2014; Yang et al., 2015; Qingyuan et al., 2012; Dong et al., 2015; Basheer et al., 2017; Fahim and Sathi, 2018).

The metal-organic framework (MOF) are compounds consisting of metal ions or clusters coordinated to organic ligands to form multi-dimensional structures. They are a subclass of coordination polymers, with special feature that are often porous. MOF materials have many advantages, including porosity, large surface area and great catalysis (Kang, 2015; Ashik et al., 2018). MOFs have drastically different catalytic activities depending on the framework present. The metal-organic framework centered with magnetic metal is easily formed through magnetic separation during catalytic separation; a prefabricated MOF with different new linkers may show different properties, such as hydrogen storage or selective catalysis (Fei, 2014; Yingya et al., 2008; Ismail and Hanafiah, 2017).

Schiff base has drawn much attention since its creation due to its good performance as ligands to form coordination complexes with metal ions. It has been reported that Schiff base metal complexes can be used for the synthesis of enzyme inhibitors(Mingrong, 2013; Elmnifi et al., 2018). Other researches also published mercapto Schiff base and its transition metal complexes but reports on their enzyme-like activities are few (Shuai, 2013; Xu, 2018; Chidumayo, 2018).

In this paper, a new magnetic MOF Fe $\mathrm{O}_{4} @ \mathrm{Fe}-\mathrm{ASB}$ was synthesized with nano- $\mathrm{Fe}_{3} \mathrm{O}_{4}$ as its metal center and new Schiff base (synthesized from quinoline-2-formaldehyde and $\beta$ mercaptoethylamine) as ligand. This paper aims to develop a colorimetric sensor to measure the concentration of ribavirin in water and animal feeds, and is based on the oxidation of ribavirin with $\mathrm{H}_{2} \mathrm{O}_{2}$, which leads to blue color of $\mathrm{H}_{2} \mathrm{O}_{2}+$ TMB system fading away. In this way, we would study the enzyme-like activity of newly synthesized MOF Fe $\mathrm{O}_{4} @ \mathrm{Fe}-\mathrm{ASB}$.

\section{Materials and Methods}

Instruments and reagents: UV-2600 Spectrophotometer (Shimadzu), D/MAX2200 X-ray Single Crystal Diffractometer (Rigaku), FTIR-8400 (Shimadzu), 1200 HPLC (Agilent Technologies), Leici PHS-3C pH Meter (Shanghai INESA Scientific Instrument Co., Ltd.) Ribavirin standard sample (Guangdong Zhaoging Star Lake Biotechnology Co., Ltd.); iron (III) chloride hexahydrate, 3,3,5,5-tetramethyl benzidine (TMB), thioglycollic acid (TGA), $\beta$-mercaptoethylamine (the abovementioned reagents were analytical reagents, purchased from Shandong West Asia Chemical Industry Co., Ltd.), glacial acetic acid $(\mathrm{HAc})$, sodium acetate trihydrate $(\mathrm{NaAc}), 25 \%$ ammonia water, $30 \% \quad \mathrm{H}_{2} \mathrm{O}_{2}$ (the above-mentioned reagents were all analytical reagents, purchased from Guangzhou Chemical Reagent Factory), ethylene glycol AR (EG) (from Tianjin Guangcheng Chemical Reagent Co., Ltd.), acetonitrile AR (Xilong Chemical Co., Ltd.), n-hexane AR (Tianjin Kermel Chemical Reagent Co., Ltd.), quinoline-2-formaldehyde AR (Shanghai Jingchun Biochemical Technology Co., Ltd.), trichloroacetic acid AR (Shanghai Lingfeng Chemical Reagent Co., Ltd.). The water used in the experiment was purified water; the feeds were pig feeds from Zhaoqing city (No. 951, 923, 902 and 983). The Water Sample No. 1 was collected from the Xijiang River.

Synthesis of magnetic metal-organic framework: Synthesis of Schiff base from quinoline-2-formaldehyde and $\beta$ mercaptoethylamine (ASB): A $0.3930 \mathrm{~g}$ of quinoline-2formaldehyde was weighed and added to a $5 \mathrm{ml}$ beaker, which contained absolute ethyl alcohol, after its full dissolution, the solution was transferred into a $50 \mathrm{ml}$ round-bottom flask. Then $0.1938 \mathrm{~g} \beta$-mercaptoethylamine was weighed and dissolved it in $5 \mathrm{ml}$ absolute ethyl alcohol. The solution was added dropwise into a flask containing quinoline-2-formaldehyde. After injection, $1 \mathrm{ml}$ glacial acetic acid was added. The reaction took $4 \mathrm{hr}$ under magnetic stirring. The temperature was maintained at $60^{\circ} \mathrm{C}$. After the reaction, the product was cooled to room temperature. Then it was dried in vacuum oven at $50^{\circ} \mathrm{C}$. After the solvent evaporated completely, the mixture was washed several times with absolute 
ethanol, and dried at $50^{\circ} \mathrm{C}$ vacuum drying oven. The product was ablood red viscous solid.

Synthesis of nano- $\mathrm{Fe}_{3} \mathrm{O}_{4}: \mathrm{A}_{3} .46 \mathrm{~g} \mathrm{FeCl}_{3}$ was dissolved in $70 \mathrm{ml}$ ethylene glycol solution under continuous stirring. After its complete dissolution, $7.66 \mathrm{~g} \mathrm{NaAc}$ was added and dissolved under stirring for another $30 \mathrm{~min}$. After its complete dissolution, the reaction liquid was divided evenly into two parts, and moved into a $50 \mathrm{ml}$ stainless steel autoclave. The reaction lasted for $8 \mathrm{hr}$ at 200 ${ }^{\circ} \mathrm{C}$ in oven. After the reaction, the product was cooled to room temperature. Then it was taken out of the oven and washed alternately with absolute ethanol and distil water 5 times. Then, the product was dried at $50^{\circ} \mathrm{C}$ and placed in sample tubes for further use.

Synthesis of $\mathrm{Fe}_{3} \mathrm{O}_{4} @ \mathrm{Fe}-\mathrm{ASB}$ : A $1.00 \mathrm{~g}$ of nano- $\mathrm{Fe}_{3} \mathrm{O}_{4}$ was prepared and placed in a beaker, and then $50 \mathrm{ml}$ of absolute ethanol was added for ultrasound aid dispersion, which lasted 20 min. After dispersion and magnetic separation, $20 \mathrm{ml}$ of $2.9 \mathrm{~m} \mathrm{~mol}$ $\mathrm{I}^{-1}$ TGA was added for ultrasound treatment for $20 \mathrm{~min}$. After completion of ultrasound dispersion, the product was put in a shaker for $1 \mathrm{hr}$. After that, we the apparatus was left overnight. The product was washed with absolute ethanol and distilled water respectively, and then $40 \mathrm{ml}$ of $10 \mathrm{mmol} \mathrm{I}^{-1} \mathrm{FeCl}_{3}$ solution was added. The reaction lasted for $1 \mathrm{hr}$ in water bath at $70^{\circ} \mathrm{C}$. After reaction, the product was washed twice with absolute ethanol and distilled water, and then $40 \mathrm{ml}$ of $10 \mathrm{mmol} \mathrm{I}^{-1} \mathrm{ASB}$ solution was added in the product. The reaction lasted for $1 \mathrm{hr}$ at $70^{\circ} \mathrm{C}$ and its product was washed three times with absolute ethanol and distilled water, respectively, and dried in a vacuum drying oven for $24 \mathrm{hr}$ at $50^{\circ} \mathrm{C}$. The final product was a bulky black solid, known as magnetic MOF catalyst.

Study of enzyme-like activity of $\mathrm{Fe}_{3} \mathrm{O}_{4} @ \mathrm{Fe}$-ASB and analysis of catalytic kinetic: $10 \mathrm{mg}$ of $\mathrm{Fe}_{3} \mathrm{O}_{4} @ \mathrm{Fe}-\mathrm{ASB}$ and $2 \mathrm{ml}$ of $0.1 \mathrm{~mol}$ $\mathrm{I}^{-1} \mathrm{HAc}-\mathrm{NaAc}$ was taken in two test tubes $(\mathrm{pH} 4)$. After vortexing for $10 \mathrm{sec}, 100 \mu \mathrm{l}$ of $8 \mathrm{mmol}^{-1} \mathrm{TMB}^{\mathrm{T}} \mathrm{Tolution}$; and in $2^{\text {nd }}$ test tube 100 $\mu \mathrm{l}$ of $\mathrm{H}_{2} \mathrm{O}_{2}$ and $100 \mu \mathrm{l}$ of $8 \mathrm{mmol} \mathrm{I}^{-1} \mathrm{TMB}$ solution was added; then we take another test tube and added $100 \mu$ of $\mathrm{H}_{2} \mathrm{O}_{2}$ solution and $100 \mu \mathrm{l}$ of $8 \mathrm{mmol} \mathrm{I}^{-1} \mathrm{TMB}$ solution. After $10 \mathrm{~min}$, absorbance was read at $652 \mathrm{~nm}$.

Detection of ribavirin: $\mathrm{A} 10 \mathrm{mg} \mathrm{Fe} \mathrm{O}_{4} @ \mathrm{Fe}-\mathrm{ASB}$ was added in a test tube first, and then $2 \mathrm{ml}$ of $0.1 \mathrm{~mol} \mathrm{I}^{-1} \mathrm{HAc}-\mathrm{NaAc}(\mathrm{pH}=4)$ was added. After vortexing for $10 \mathrm{sec}, 100 \mu \mathrm{l}$ of $\mathrm{H}_{2} \mathrm{O}_{2}$ and $100 \mu \mathrm{l}$ of ribavirin solution was added. The solution was incubated for 10 $\mathrm{min} .100 \mu \mathrm{l}$ of $8 \mathrm{mmoll}^{-1} \mathrm{TMB}$ solution was added to terminate the color for $10 \mathrm{~min}$, the absorption of each was measured at $652 \mathrm{~nm}$ with UV detection. Both incubation and reaction took place at 35 ${ }^{\circ} \mathrm{C}$.

Pretreatment of Water sample: The water samples were collected from Zhaoqing part of Xijiang River and boiled for $1 \mathrm{~min}$ and filtered for detection.
Feed sample: Before treatment, the feed sample was dried in 60 ${ }^{\circ} \mathrm{C}$ vacuum oven for $4 \mathrm{hr}$. Then, $2 \mathrm{~g}$ of feed sample was taken a centrifuge tube and $10 \mathrm{ml}$ of acetonitrile- $1 \%$ trichloroacetic acid (70:30) was added. After vortexing for $1 \mathrm{~min}$, the solution was centrifuge for $5 \mathrm{~min}$ at $10000 \mathrm{r} \mathrm{min}^{-1}$. Then clear supernatant was transferred into another $50 \mathrm{ml}$ centrifuge tube and $10 \mathrm{ml}$ of $\mathrm{n}$ hexane was added. After vortexing for $30 \mathrm{sec}$, the solution was centrifuged for $5 \mathrm{~min}$ at $10000 \mathrm{r} \mathrm{min}^{-1}$. The upper solution was discarded, and the lower solution was adjusted to $\mathrm{pH} 8.5 \pm 0.1$ with ammonia water. After centrifuge for $5 \mathrm{~min}$, the eluent was filtered for further detection (Kai et al., 2014). HPLC detection conditions were as follows: the column was ODS-BP column $(4.6 \times 250 \mathrm{~mm}$, $5 \mu \mathrm{m})$, mobile phase was a solution of methanol: water (adjusted to $\mathrm{pH}=4$ with sulfuric acid) $=12: 88(\mathrm{~V} / \mathrm{V})$, the flow rate was 0.8 $\mathrm{ml} \cdot \mathrm{min}^{-1}$. Three types of wavelengths were adopted, $207 \mathrm{~nm}$ for ribavirin, $254 \mathrm{~nm}$ for carnine, $260 \mathrm{~nm}$ for uridine and $20 \mu$ for the sample.

\section{Results and Discussion}

Reaction mechanism: Fig. 1, 2, 3 shows the reaction mechanism. The ribavirin adduct LC-MS and ribavirin LC-MS are shown in Fig. 5 and Fig. 4. The molecular ion peak was at $245 \mathrm{mz}^{-1}$. The peak of ribavirin sodium salt dihydrate was the number remained same after binding, indicating that the adduct reaction was incomplete. Before binding, the peak at $268 \mathrm{~m} \mathrm{z}^{-1}$ was high, while peak at $303 \mathrm{~m} \mathrm{z}^{-1}$ was low. In contrast, after binding, the peak at $268 \mathrm{~m} \mathrm{z}^{-1}$ fell, while the peak at $303 \mathrm{~m} \mathrm{z}^{-1}$ rose. The peak at 268 $m z^{-1}$ was the molecular ion peak of ribavirin sodium salt, while peak at $303 \mathrm{~m} \mathrm{z}^{-1}$ was the molecular ion peak of adduct formed from ribavirin and $\mathrm{H}_{2} \mathrm{O}_{2}$, with an increase of molecular weight equaling 34 .

Characterization of $\mathrm{Fe}_{3} \mathrm{O}_{4} @ \mathrm{Fe}-\mathrm{ASB}$ : Fig. 6 shows the characterization of ASB. The peak at $301 \mathrm{~nm}$ of UV spectrum of quinoline-2-formaldehyde was the absorption peak of $\mathrm{C}=\mathrm{O}$ bond. In the reaction, the $\mathrm{C}=\mathrm{O}$ bond reacted with $\mathrm{NH}_{2}$ and formed $\mathrm{C}=\mathrm{N}$ double bond, so there no peak at $301 \mathrm{~nm}$. A new peak appeared, compared with the UV spectrum of quinoline-2-formaldehyde. It was the characteristic absorption peak of $\mathrm{C}=\mathrm{N}$ double bond. Due to formation of ASB from quinoline-2-formaldehyde and $\beta$ mercaptoethylamine, two peaks at $203 \mathrm{~nm}$ and $231 \mathrm{~nm}$ were redshifted.

The above graph was infrared band of ASB $(A)$. The peak at $3400.98 \mathrm{~cm}^{-1}$ was sharp, while the characteristic absorption peaks at $2300.58 \mathrm{~cm}^{-1}$ and $2062.95 \mathrm{~cm}^{-1}$ were weak. They were the characteristic absorption peaks of $\mathrm{S}-\mathrm{H}$ bond. The peaks at $2937.69 \mathrm{~cm}^{-1}$ and $1380.09 \mathrm{~cm}^{-1}$ were due to stretching vibrations of $\mathrm{C}-\mathrm{H}$ bond in methylene; the peak at $1659.16 \mathrm{~cm}^{-1}$ was the characteristic absorption peak of $\mathrm{C}=\mathrm{C}-\mathrm{C}=\mathrm{C}$ bond and $\mathrm{C}=\mathrm{N}$ bond; the peak at $916.00 \mathrm{~cm}^{-1}$ was due to stretching vibrations of $\mathrm{C}-\mathrm{N}$ bond, whereas peak at $620.59 \mathrm{~cm}^{-1}$ resulted from out of plane bending of unsaturated olefin $\mathrm{C}-\mathrm{H}$. 
<smiles>N/C(=N/N=C(/N)C(=O)O)OC(CO)CO</smiles>

Ribavirin - - $268 \mathrm{~m} \mathrm{z}$

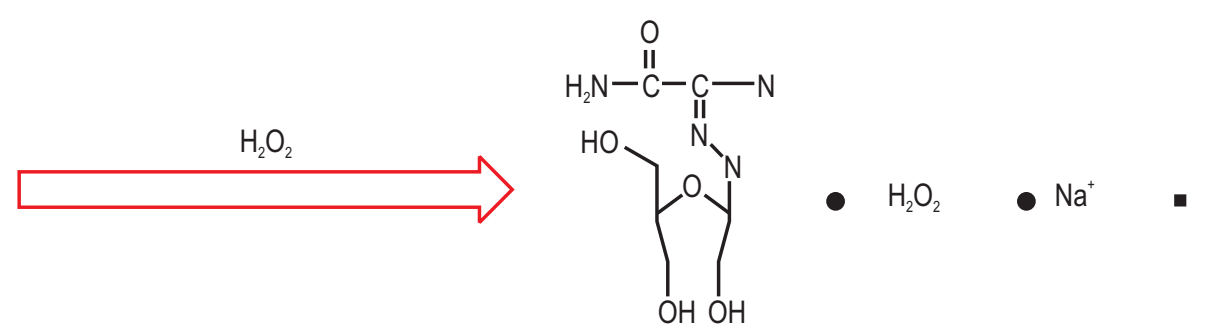

Ribavirin - - $303 \mathrm{~m} \mathrm{z}^{-1}$

Fig. 1 : Ribavirin adduct reaction Ribavirin $268 \mathrm{~m} / \mathrm{z}$ Ribavirin adduct $303 \mathrm{~m} \mathrm{z}^{-1}$.
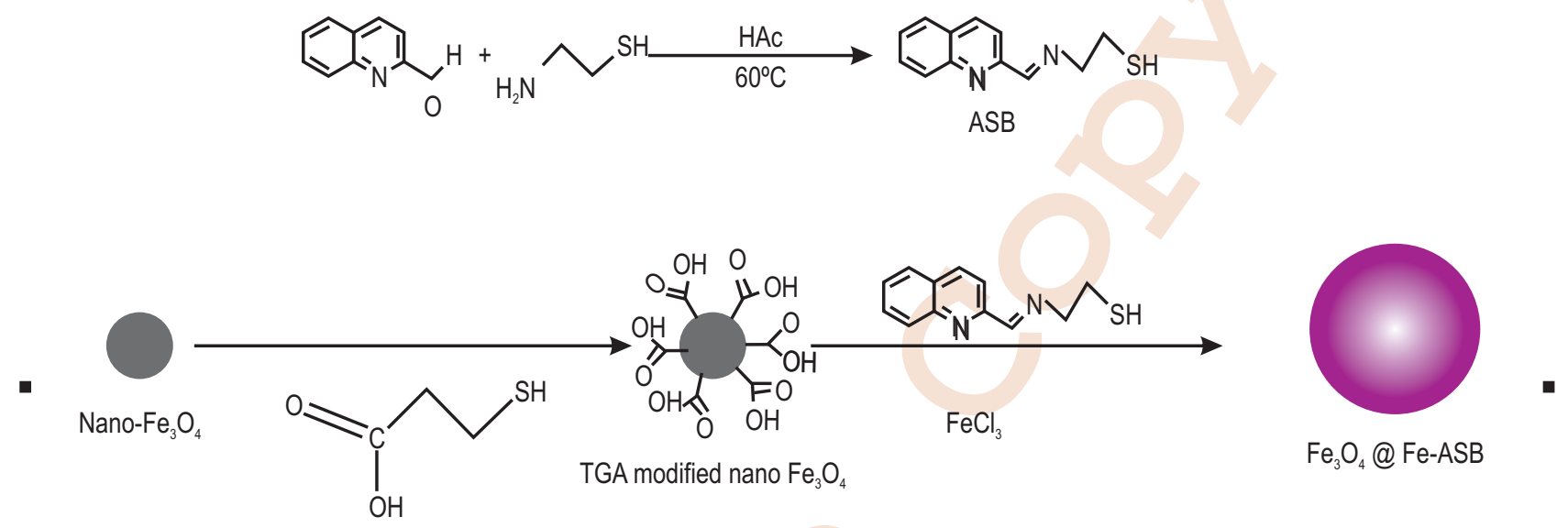

Fig. 2 : Synthesis route of catalyst $\mathrm{Nano}-\mathrm{Fe}_{3} \mathrm{O}_{4} \mathrm{TGA}$ modified nano- $-\mathrm{Fe}_{3} \mathrm{O}_{4}$.

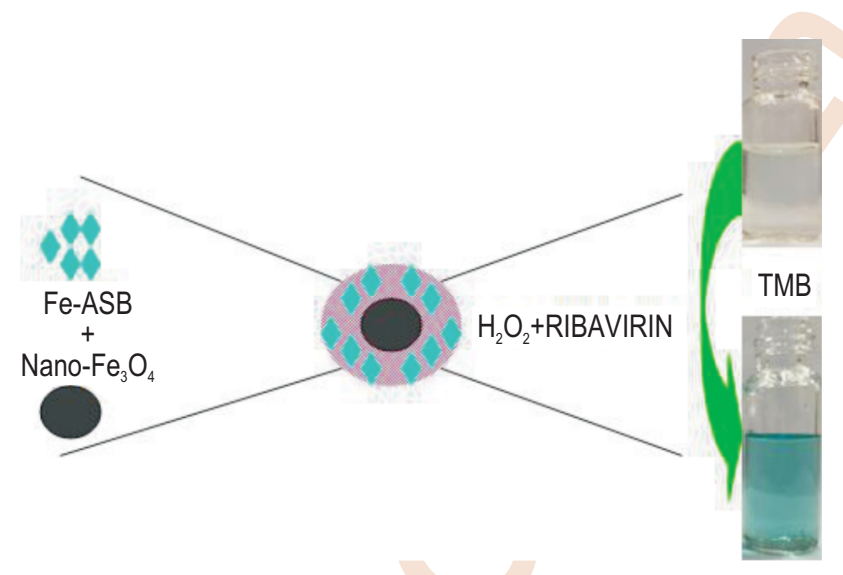

Fig. 3 : Principle of ribavirin detection with colorimetric method Nano$\mathrm{Fe}_{3} \mathrm{O}_{4}$.

As shown in the infrared spectrum of $\mathrm{Fe}_{3} \mathrm{O}_{4} @ \mathrm{Fe}-\mathrm{ASB}$ and $\mathrm{Fe}_{3} \mathrm{O}_{4}$, an obvious absorption peak appeared at $591.5 \mathrm{~cm}^{-1}$ of $\mathrm{Fe}_{3} \mathrm{O}_{4}$ spectrum. It was the characteristic absorption peak of $\mathrm{Fe}_{3} \mathrm{O}_{4}$. The characteristic absorption peak of $\mathrm{Fe}_{3} \mathrm{O}_{4}$ lies in 474.10 $\mathrm{cm}^{-1}$ of spectrum of $\mathrm{Fe}_{3} \mathrm{O}_{4} @ \mathrm{Fe}-\mathrm{ASB}$. After the magnetic MOF wrapped the $\mathrm{Fe}_{3} \mathrm{O}_{4}$, the characteristic absorption peak of $\mathrm{Fe}_{3} \mathrm{O}_{4}$ blue-shifted. The absorption peak at $1084.01 \mathrm{~cm}^{-1}$ of $\mathrm{Fe}_{3} \mathrm{O}_{4} @ \mathrm{Fe}-$ ASB spectrum was the ligand peak of Fe-ASB.
Fig. 8 shows the SEM images of $\mathrm{Fe}_{3} \mathrm{O}_{4} @ \mathrm{Fe}-\mathrm{ASB}$. The $\mathrm{Fe}_{3} \mathrm{O}_{4} @ \mathrm{Fe}-\mathrm{ASB}$ had high dispersion and its particles were uniform in size and round in shape. The diameter of $\mathrm{Fe}_{3} \mathrm{O}_{4} @ \mathrm{Fe}-$ AS was about $280 \mathrm{~nm}$, as shown in Fig. 8(B).

Fig. 9 shows the XRD diagram of $\mathrm{Fe}_{3} \mathrm{O}_{4} @ \mathrm{Fe}-\mathrm{ASB}$. The diffraction peaks of self-made XRD diagrams of $\mathrm{Fe}_{3} \mathrm{O}_{4}(\mathrm{a})$ and $\mathrm{Fe}_{3} \mathrm{O}_{4} @ \mathrm{Fe}-\mathrm{ASB}$ (b) were consistent. So, did the diffraction peaks of self-made $\mathrm{Fe}_{3} \mathrm{O}_{4}(\mathrm{a})$ and JCPDS 65-3107, corresponding to (220), (311), (400), (422), (511), and (440) crystal planes of $\mathrm{Fe}_{3} \mathrm{O}_{4}$, respectively. Although the diffraction peaks of $\mathrm{Fe}_{3} \mathrm{O}_{4} @ \mathrm{Fe}-\mathrm{ASB}(\mathrm{b})$ and $\mathrm{Fe}_{3} \mathrm{O}_{4}(\mathrm{a})$ were consistent, their intensity and width were not same due to the magnetic MOF that wrapped the $\mathrm{Fe}_{3} \mathrm{O}_{4} @ \mathrm{Fe}$ ASB. However, such magnetic MOF did not affect the original crystal structure of $\mathrm{Fe}_{3} \mathrm{O}_{4}$ (Donglan, 2013).

Study of enzyme-like activity of $\mathrm{Fe}_{3} \mathrm{O}_{4} @ \mathrm{Fe}-\mathrm{ASB}$ : $\mathrm{Fe}_{3} \mathrm{O}_{4} @ \mathrm{Fe}-$ ASB has enzyme-like activity, and acts as a catalyst for $\mathrm{H}_{2} \mathrm{O}_{2}$, which oxidizes its substrate to develop color. In the absence of catalyst, such process cannot be realized. Better enzyme-like activity of the catalyst will result in faster catalytic reaction and more obvious rendering of color. To study the enzyme-like activity of $\mathrm{Fe}_{3} \mathrm{O}_{4} @ \mathrm{Fe}-\mathrm{ASB}$, a comparative experiment was conducted. Fig. 10 shows the presence of only $\mathrm{H}_{2} \mathrm{O}_{2}$ and TMB substrate, the 
RT:0.00-0.05

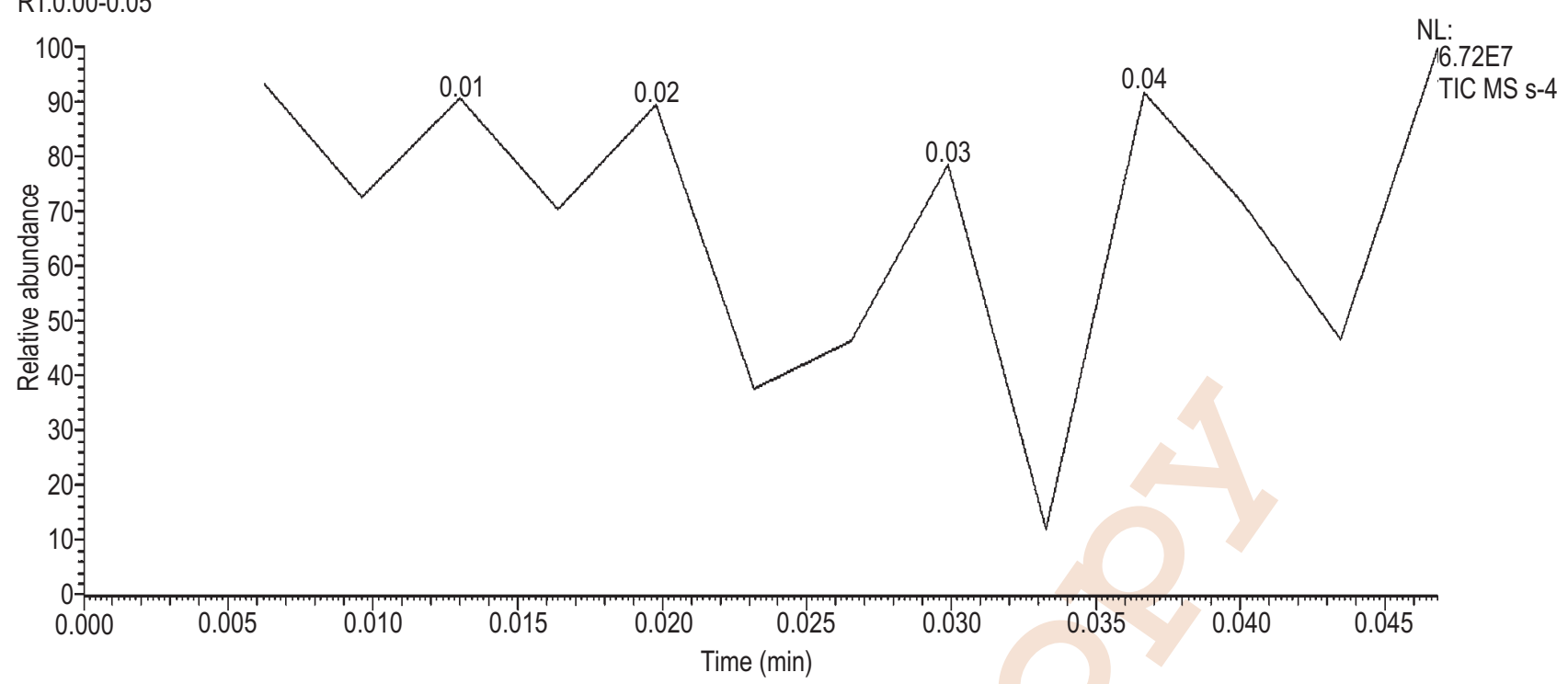

S-4 \#1 RT: 0.01 AV: 1 NL: 6.03E6

T: FTMS + pESI Full ms [200.00-800.00]

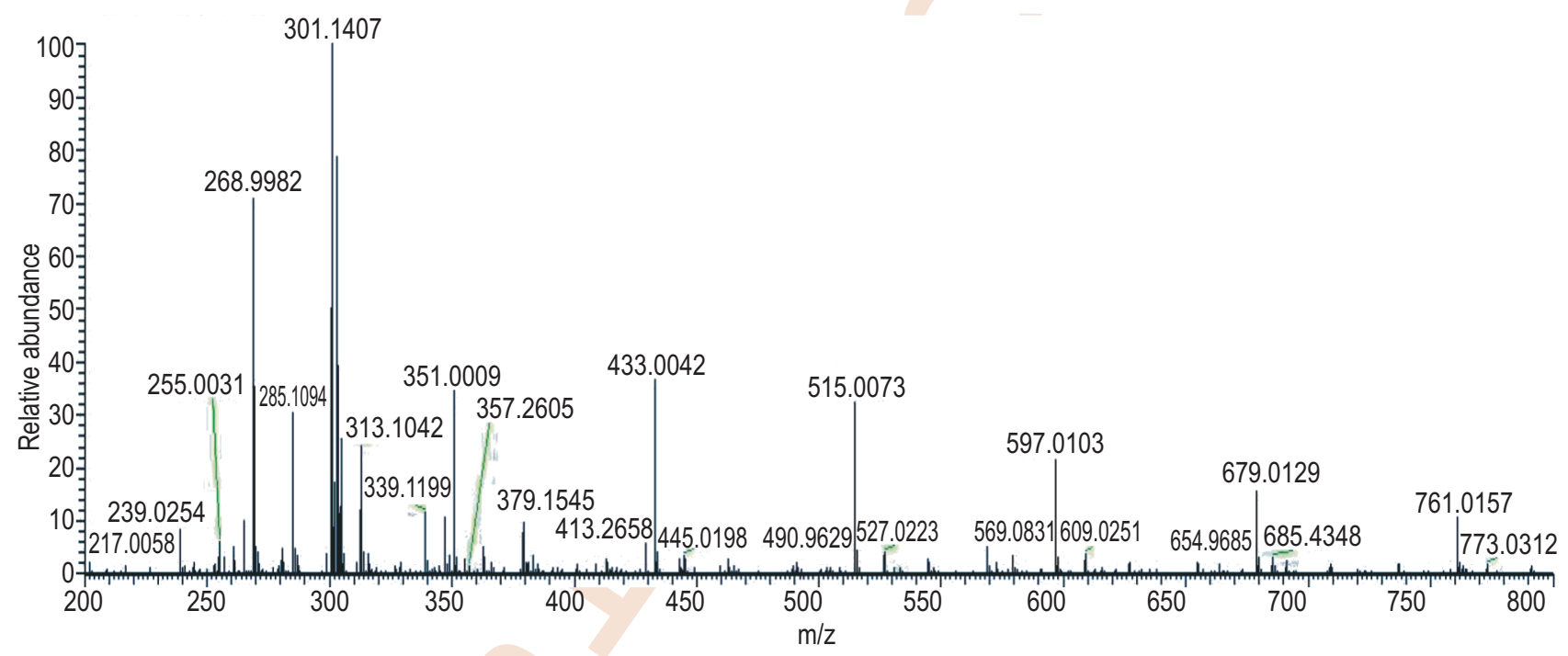

Fig. 4 : Ribavirin LC-MS.

solution was colorless and transparent, indicating that the $\mathrm{H}_{2} \mathrm{O}_{2}$ in the system did not oxidize the substrate TMB and develop color. In the presence of catalyst and TMB substrate, the solution was light blue because a trace amount of oxygen had dissolved in the solution. So in the presence of catalyst, oxygen reacted with $\mathrm{H}^{+}$ ions and produced $\mathrm{HO}_{2}$, which then oxidized the TMB substrate and rendered color. In the presence of catalyst, $\mathrm{H}_{2} \mathrm{O}_{2}$ and substrate TMB, the solution showed transparent blue because a large amount of $\mathrm{H}_{2} \mathrm{O}_{2}$ had oxidized TMB colour substrate and developed the color (Yang et al., 2015; Nawaz et al., 2018). Coloration was obvious, which proved that $\mathrm{Fe}_{3} \mathrm{O}_{4} @ \mathrm{Fe}-\mathrm{AS}$ has a good enzyme-like activity.

Many researches have reported (GAO Q. et al., 2011) the catalytic activity of nano- $\mathrm{Fe}_{3} \mathrm{O}_{4}$. Some researchers demonstrated that certain metal-organic frameworks had catalytic activity. To understand whether the combination of both nano- $\mathrm{Fe}_{3} \mathrm{O}_{4}$ and magnetic metal-organic frameworks can increase catalytic effects, a comparative experiment was conducted. The result is shown in Fig. 11.

The absorbance of both MOF (a) and $\mathrm{Fe}_{3} \mathrm{O}_{4}$ (b) was lower than that of $\mathrm{Fe}_{3} \mathrm{O}_{4} @ \mathrm{Fe}-\mathrm{ASB}$ (c), which approved the synergy of $\mathrm{Fe}_{3} \mathrm{O}_{4}$ and MOF. Therefore, $\mathrm{Fe}_{3} \mathrm{O}_{4} @ \mathrm{Fe}-\mathrm{ASB}$ showed better enzyme-like activity than the other two. Fig. 12 showed that the curve of absorbance varied with the amount of catalyst. Fig. 12 shows that the absorbance increased as the amount of catalyst was increased, but with decreased effect, indicating that the 

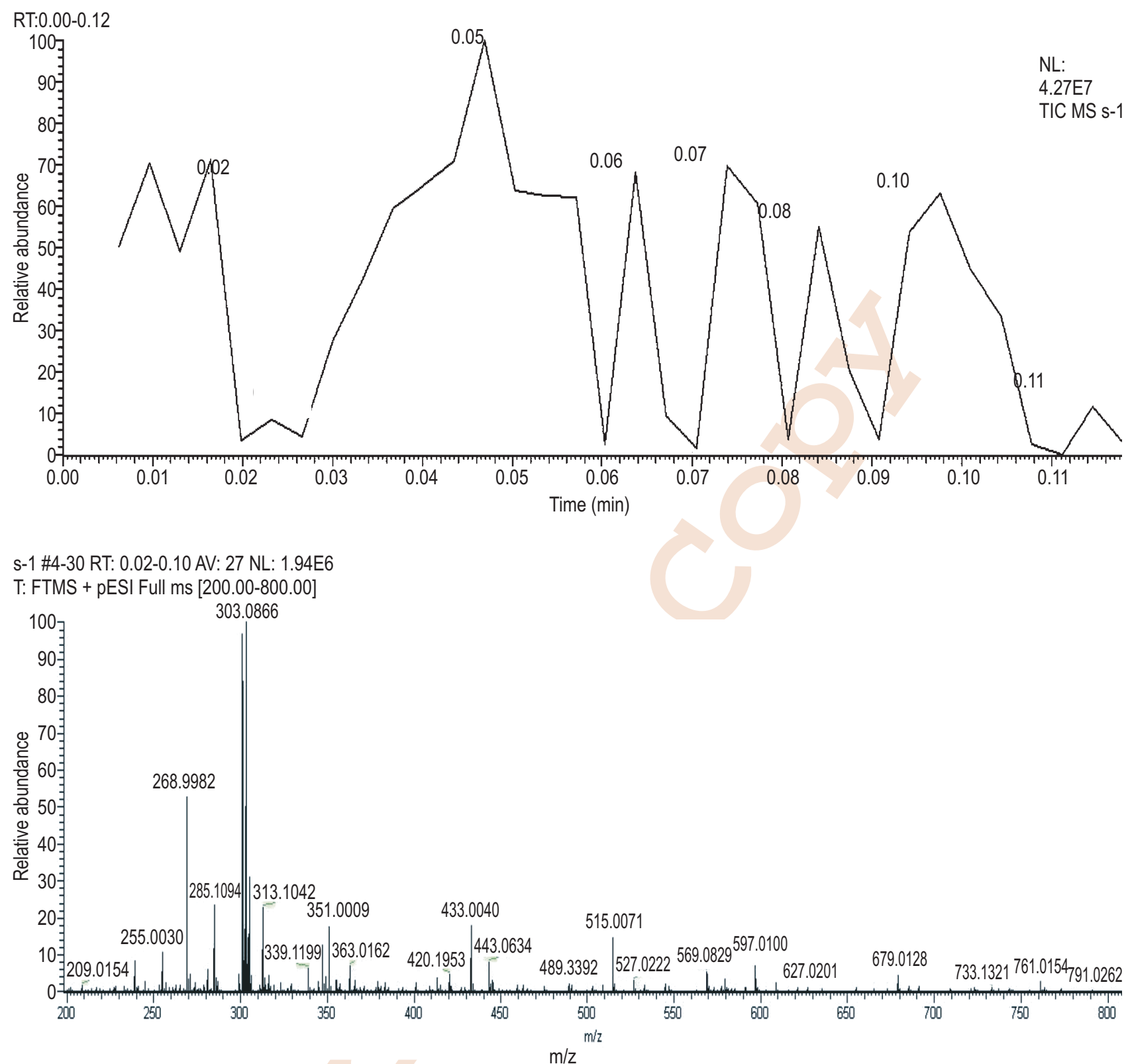

Fig. 5 : Ribavirin adduct LC-MS.

maximum reaction rate would reach a balance as the amount of catalyst was increased. After taking all factors into consideration, the experiment used $10 \mathrm{mg}$ catalyst as the optimal catalyst amount.

Analysis of catalytic kinetic of $\mathrm{Fe}_{3} \mathrm{O}_{4} @ \mathrm{Fe}-\mathrm{ASB}$ : To further understand the enzymatic activity of $\mathrm{Fe}_{3} \mathrm{O}_{4} @ \mathrm{Fe}-\mathrm{ASB}$ in simulating enzyme, the $\mathrm{K}_{\mathrm{m}}$ of $\mathrm{H}_{2} \mathrm{O}_{2}$ and $\mathrm{TMB}$ substrate in $\mathrm{Fe}_{3} \mathrm{O}_{4} @ \mathrm{Fe}$-ASB was measured, using same data of self-made $\mathrm{Fe}_{3} \mathrm{O}_{4}$ as a comparing group. Michlet constant $\left(\mathrm{K}_{\mathrm{m}}\right)$ is a enzymes constant affected by reaction conditions, properties of substrates and to enzymes. Smaller the $\mathrm{K}_{\mathrm{m}}$, greater is the affinity of enzymes to substrates, and to reach the maximum reaction rate becomes quicker and easier. On the contrary, greater the $\mathrm{K}_{\mathrm{m}}$, value smaller is the affinity of enzymes to substrates, and to reach the maximum reaction rate becomes slower and more difficult. The Michlet constant is usually calculated with double-reciprocal plot of the Michaelis-Menten equation.

$$
v=\frac{\Delta c}{\Delta t}=\frac{\frac{\Delta A}{\varepsilon b}}{\Delta t}
$$




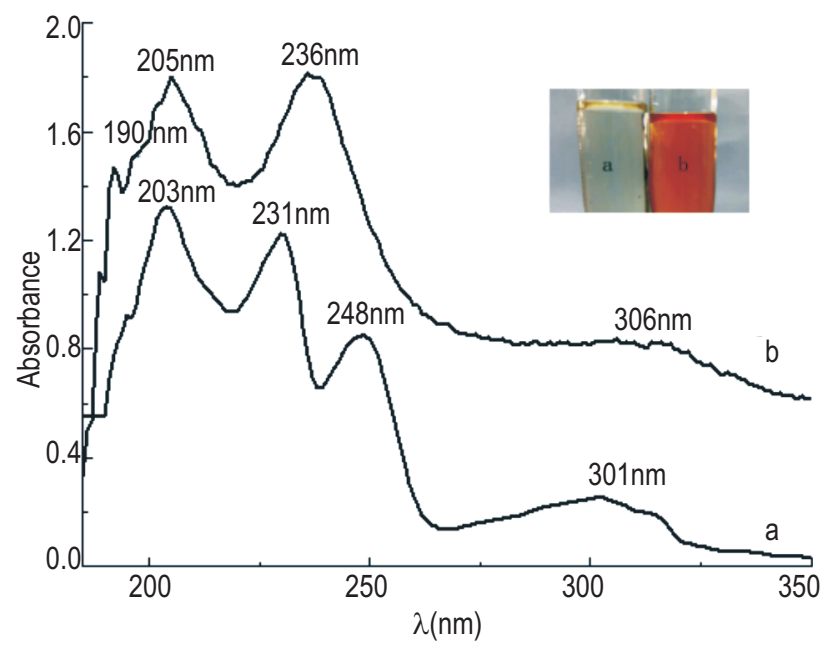

Fig. 6 : UV spectra of quinoline-2-formaldehyde (a) and ASB (b)
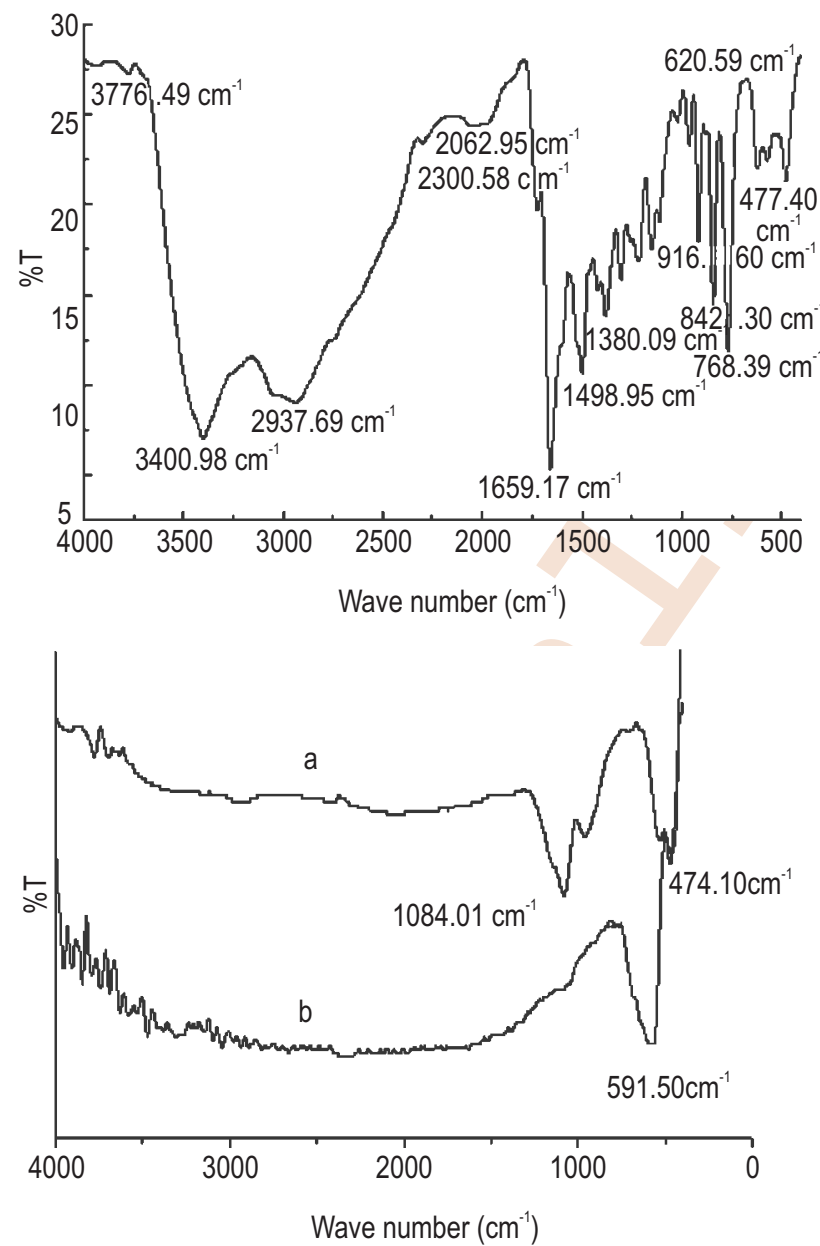

Fig. 7 : Infrared spectra of $\mathrm{ASB}(\mathrm{A}), \mathrm{Fe}_{3} \mathrm{O}_{4} @ \mathrm{Fe}-\mathrm{ASB}(\mathrm{a})$ and $\mathrm{Fe}_{3} \mathrm{O}_{4}(\mathrm{~b})$.
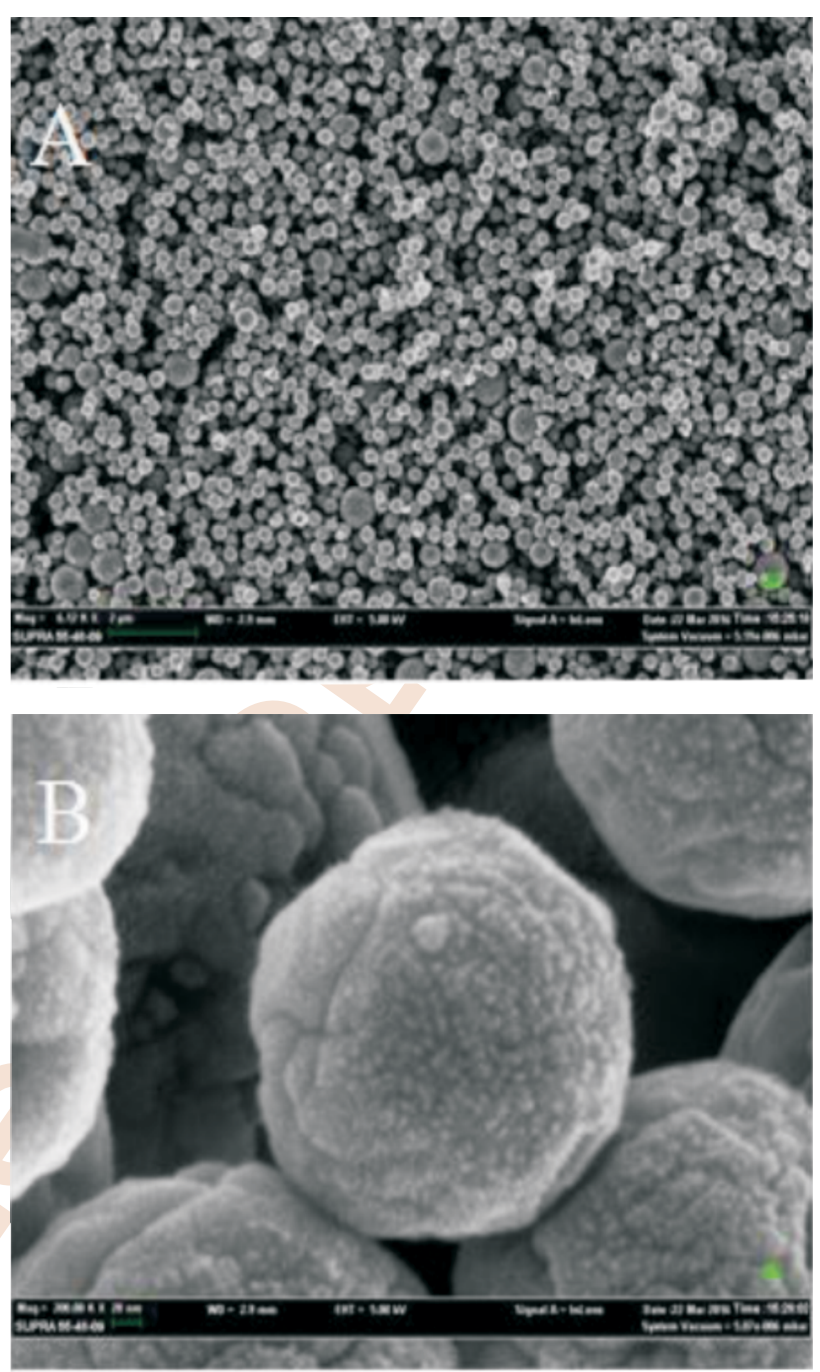

Fig. 8 : SEM images of $\mathrm{Fe}_{3} \mathrm{O}_{4} @ \mathrm{Fe}-\mathrm{ASB}$

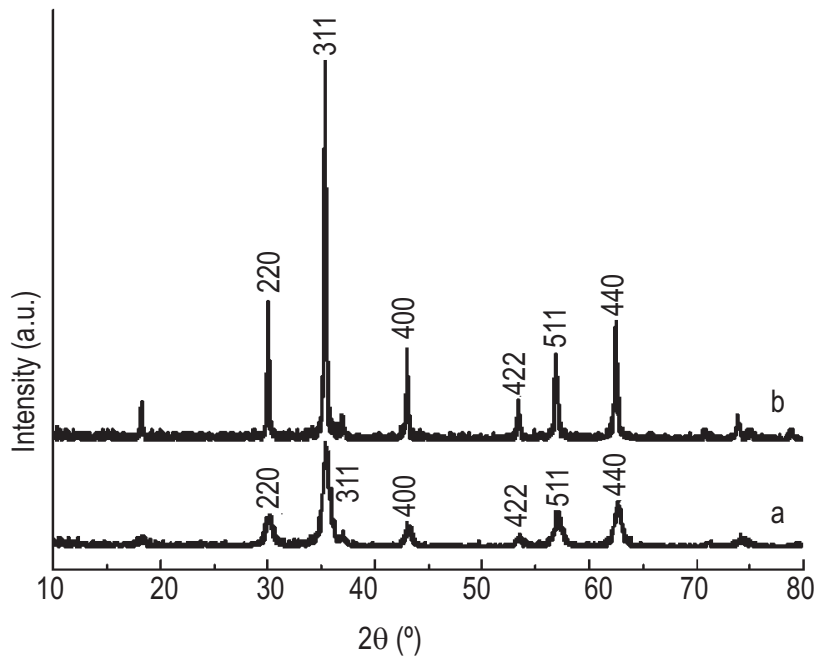

Fig. 9 : XRD diagrams of $\mathrm{Fe}_{3} \mathrm{O}_{4}(\mathrm{a})$ and $\mathrm{Fe}_{3} \mathrm{O}_{4} @ \mathrm{Fe}-\mathrm{ASB}(\mathrm{b})$. 


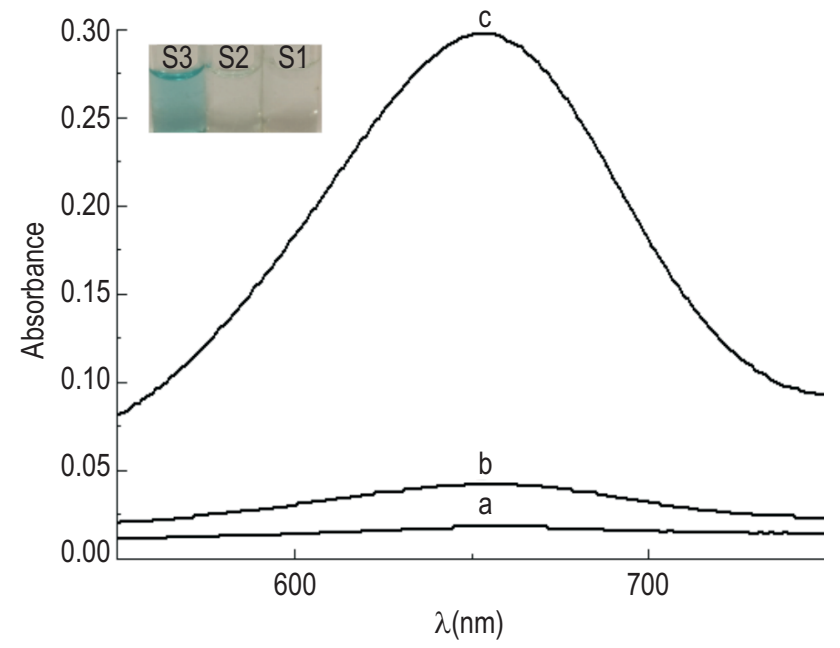

Fig. 10 : Study of the enzyme-like activity of $\mathrm{Fe}_{3} \mathrm{O}_{4} @ \mathrm{Fe}-\mathrm{ASB} \mathrm{H}_{2} \mathrm{O}_{2}+\mathrm{TMB}$ (a); $\mathrm{Fe}_{3} \mathrm{O}_{4} @ \mathrm{Fe}-\mathrm{ASB}+\mathrm{TMB}(\mathrm{b}) ; \mathrm{Fe}_{3} \mathrm{O}_{4} @ \mathrm{Fe}-\mathrm{ASB}+\mathrm{H}_{2} \mathrm{O}_{2}+\mathrm{TMB}$ (c).

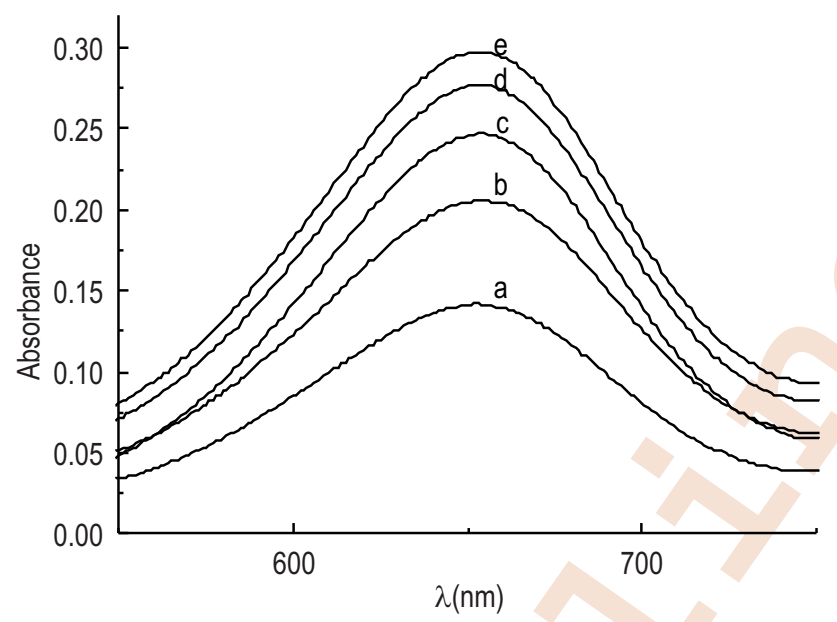

Fig. 12 : Curve of absorbance varying with the amount of catalyst $2 \mathrm{mg}$ (a); 4 mg (b); 6 mg (c); 8 mg(d); 10 mg (e) 2 mg (a); 4 mg (b); 6 mg (c); 8 $\mathrm{mg}(\mathrm{d}) ; 10 \mathrm{mg}(\mathrm{e})$.

In Equation (1), $\Delta A$ is the variation of absorbance in $\Delta t$, the molar absorptivity of the product from oxidation of TMB substrate, known as $\varepsilon$, at $652 \mathrm{~nm}: \varepsilon_{652}=39000 \mathrm{M}^{-1} \mathrm{~cm}^{-1}$, the thickness of colorimetric pond, known as $b$, was $1 \mathrm{~cm}$.

After the initial reaction rate was obtained, according to the double-reciprocal plot of Michaelis-Menten equation:

$$
\frac{1}{v}=\frac{K m}{V m} \cdot \frac{1}{[s]}+\frac{1}{V m}
$$

In Equation (2), $v$ is the initial reaction rate; $V_{m}$ is the maximum reaction rate; $S$ is the substrate concentration; and $K_{m}$ is the Michlet constant.

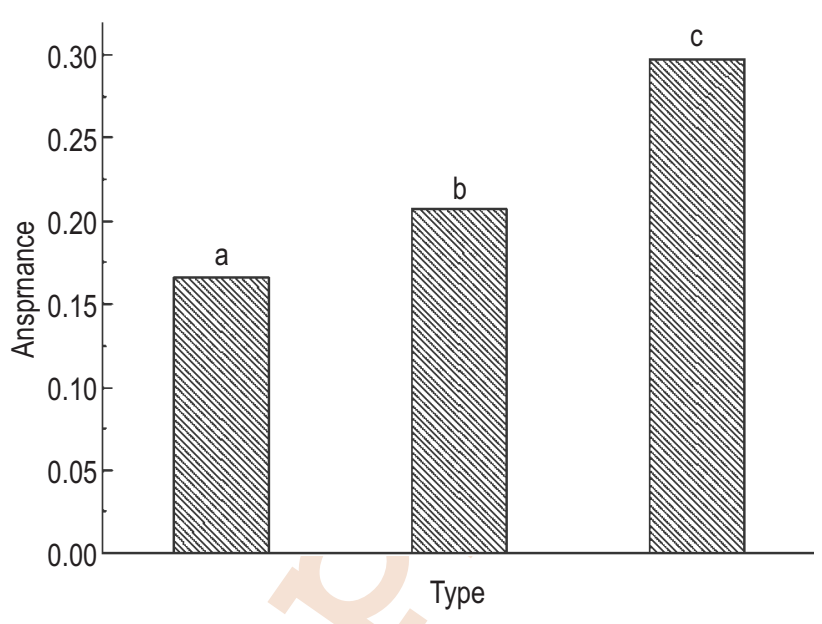

Fig. 11 : Comparison of enzyme-like activity of different catalysts Metalorganic framework (a); $\mathrm{Fe}_{3} \mathrm{O}_{4}(\mathrm{~b}) ; \mathrm{Fe}_{3} \mathrm{O}_{4} @ \mathrm{Fe}-\mathrm{ASB}(\mathrm{c})$.
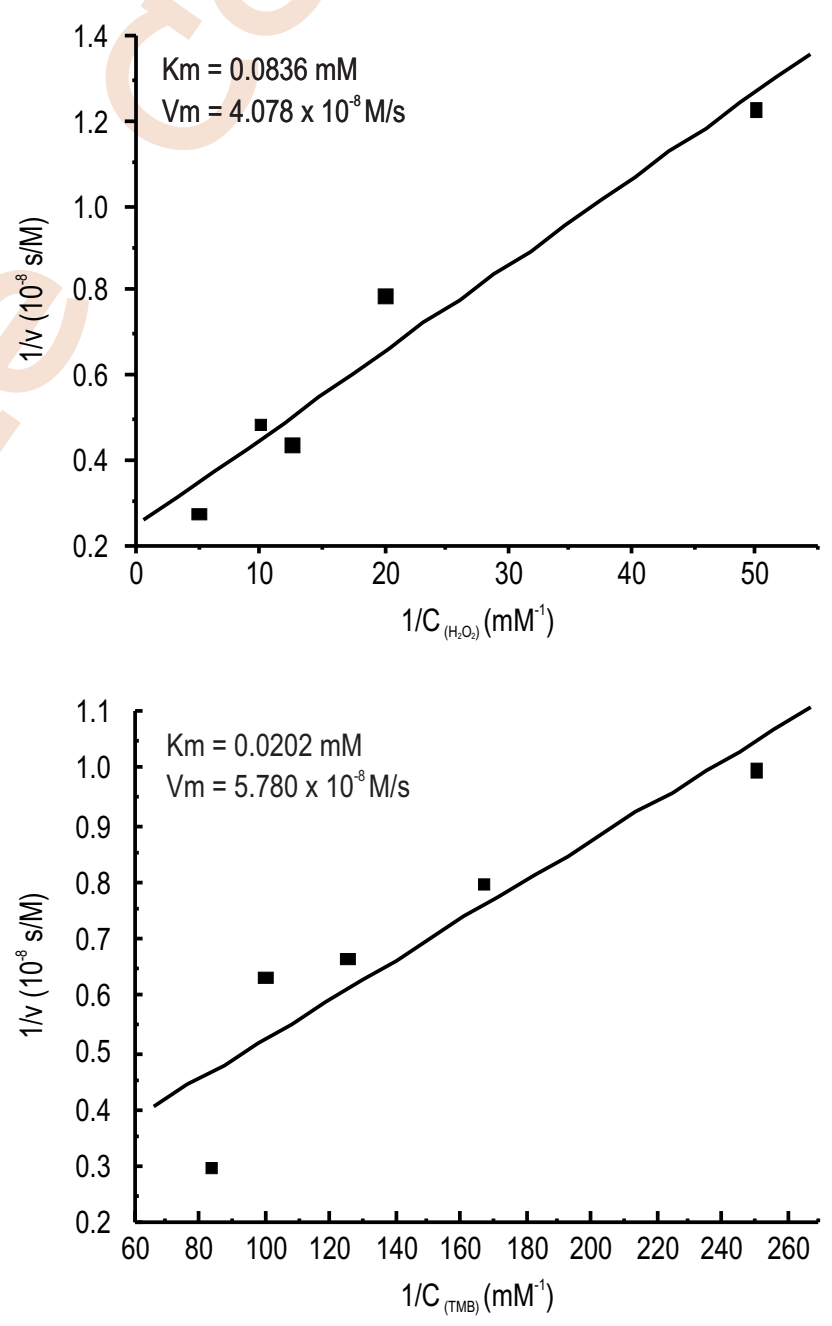

Fig. 13: Michaelis-Menten equations for $\mathrm{Fe}_{3} \mathrm{O}_{4} @ \mathrm{Fe}-\mathrm{ASB}$ catalyzing $\mathrm{H}_{2} \mathrm{O}_{2}$ (left) and substrate TMB (right). 
Table 1: $\mathrm{K}_{\mathrm{m}}$ and $\mathrm{V}_{\mathrm{m}}$ for different catalysts and substrates

\begin{tabular}{llll}
\hline Catalyst & Substrate & $\mathrm{K}_{\mathrm{m}}(\mathrm{mM})$ & $\mathbf{V}_{\mathrm{m}}\left(\mathbf{M} \cdot \mathbf{s}^{-1}\right)$ \\
\hline $\mathrm{Fe}_{3} \mathrm{O}_{4}$ & $\mathrm{H}_{2} \mathrm{O}_{2}$ & 0.324 & $3.921 \times 10^{-8}$ \\
$\mathrm{Fe}_{3} \mathrm{O}_{4}$ & $\mathrm{TMB}$ & 0.038 & $7.750 \times 10^{-8}$ \\
$\mathrm{Fe}_{3} \mathrm{O}_{4} @ \mathrm{Fe}-\mathrm{ASB}$ & $\mathrm{H}_{2} \mathrm{O}_{2}$ & 0.084 & $4.078 \times 10^{-8}$ \\
$\mathrm{Fe}_{3} \mathrm{O}_{4} \mathrm{Fe}-\mathrm{ASB}$ & $\mathrm{TMB}$ & 0.020 & $5.780 \times 10^{-8}$ \\
$\mathrm{HRP}[20]$ & $\mathrm{H}_{2} \mathrm{O}_{2}$ & 3.70 & $8.710 \times 10^{-8}$ \\
$\mathrm{HRP}[20]$ & $\mathrm{TMB}$ & 0.434 & $1.000 \times 10^{-7}$ \\
\hline
\end{tabular}

Table 2: Recovery rate and standard error of water samples $(n=3)$

\begin{tabular}{llllll}
\hline Sample & $\begin{array}{l}\text { Measured value } \\
(\mathrm{mM})\end{array}$ & $\begin{array}{l}\text { Addition amount } \\
(\boldsymbol{\mu M})\end{array}$ & $\begin{array}{l}\text { Average recovery } \\
\text { amount }(\boldsymbol{\mu M})\end{array}$ & $\begin{array}{l}\text { Recovery rate } \\
(\%)\end{array}$ & $\begin{array}{l}\text { Standard } \\
\text { error }(\%)\end{array}$ \\
\hline Water sample & ND & 5.00 & 4.60 & 92.0 & 1.1 \\
& & 10.0 & 10.9 & 109 & 2.7 \\
Feed sample & ND & 50.0 & 5.23 & 105 & 3.1 \\
& & 5.00 & 5.20 & 104 & 1.1 \\
& 10.0 & 9.80 & 98.0 & 1.8 \\
\hline
\end{tabular}

ND: not detected

Catalyst was weighed in its precise amount, and changed substrate concentration, with other conditions remained the same, to draw a graph of absorbance vs. time at $652 \mathrm{~nm}$. The time for catalytic reaction of substrate was $120 \mathrm{sec}$ and $240 \mathrm{sec}$. The concentration of products at different time was calculated based on the Lambert's Law. According to double-reciprocal plot of Michaelis-Menten equation, two linear equations were made with $1 / \mathrm{c}\left(\mathrm{H}_{2} \mathrm{O}_{2}\right) / \mathrm{mM}^{-1}$ as $\mathrm{X}$-axis and $1 / \mathrm{v} / 10^{-8} \mathrm{~s} \cdot \mathrm{M}^{-1}$ as $\mathrm{Y}$-axis. Then Michaelis constant of $\mathrm{K}_{\mathrm{m}}$ was calculated and the maximum reaction rate of $V_{m}$, based on the regression equation. The intercept on $\mathrm{X}$-axis was the absolute value of reciprocal of $\mathrm{K}_{\mathrm{m}}$, and intercept on $Y$-axis was $V_{m}$. Fig. 13 shows that Michaelis-Menten equation for $\mathrm{Fe}_{3} \mathrm{O}_{4} @ \mathrm{Fe}-\mathrm{ASB}$ catalyzing $\mathrm{H}_{2} \mathrm{O}_{2}$ is as follows: $y=0.0205 x+2452$, in which $K_{m}=0.0836 \mathrm{mM}$ and $V_{m}=4.078 \times 10^{-8}$ $M \cdot s^{-1}$. Fig. 13 also shows the Michaelis-Menten equation for $\mathrm{Fe}_{3} \mathrm{O}_{4} @ \mathrm{Fe}-\mathrm{ASB}$ catalyzing TMB t: $\mathrm{y}=0.0035 \mathrm{x}+0.173$, in which $\mathrm{K}_{\mathrm{m}}=0.0202 \mathrm{mM}$ and $\mathrm{V}_{\mathrm{m}}=5.780 \times 10^{-8} \mathrm{M} \cdot \mathrm{s}^{-1}$ (Table 1).

Table shows that whether the substrate was $\mathrm{H}_{2} \mathrm{O}_{2}$ or TMB, the $\mathrm{K}_{\mathrm{m}}$ of $\mathrm{Fe}_{3} \mathrm{O}_{4} @ \mathrm{Fe}-\mathrm{ASB}$ was lower than that of $\mathrm{Fe}_{3} \mathrm{O}_{4}$ and HRP. The affinity of $\mathrm{Fe}_{3} \mathrm{O}_{4} @ \mathrm{Fe}-\mathrm{ASB}$ to substrate was greater than that of $\mathrm{Fe}_{3} \mathrm{O}_{4}$ and $\mathrm{HRP}$. With equal substrate concentration, $\mathrm{Fe}_{3} \mathrm{O}_{4} @ \mathrm{Fe}-\mathrm{ASB}$ reached the maximum reaction faster than $\mathrm{Fe}_{3} \mathrm{O}_{4}$ and HRP. Therefore, $\mathrm{Fe}_{3} \mathrm{O}_{4} @ \mathrm{Fe}-\mathrm{ASB}$ showed better enzymatic activity.

Optimization of detection conditions: Optimization of $\mathrm{pH}$ : Fig. 14 shows that the color of buffer solution was most intense at $\mathrm{pH}$ 3. As pH increased, the intensity of color decreased. The absorbance curve leveled out slightly at $\mathrm{pH} 4$ and then fell again. At pH 5, the color slowly disappeared because under neutral or alkaline conditions $\mathrm{H}_{2} \mathrm{O}_{2}$ exhibits reducing property instead of oxidizing property, even catalyst are not able to oxidize the substrate TMB and develop color. Fig. 14 shows that $\mathrm{pH} 3$ the most favorable condition to develop color. However, at $\mathrm{pH} 3, \mathrm{Fe}^{3+}$ may dissolve into the solution from $\mathrm{Fe}_{3} \mathrm{O}_{4} @ \mathrm{Fe}-\mathrm{ASB}$, and there is a high concentration of $\mathrm{H}^{+}$, resulting in the interference, which leads to unstable coloration of solution. Given that, the experiment was carried out with $0.1 \mathrm{moll}^{-1} \mathrm{HAc}-\mathrm{NaAc}$ buffer solution at $\mathrm{pH} 4$.

Optimization of incubation time: Fig. 15 shows the incubation time, i.e., the reaction time of $\mathrm{H}_{2} \mathrm{O}_{2}$ and ribavirin. Higher $\mathrm{H}_{2} \mathrm{O}_{2}$ was consumed, less obvious the color was for the system. Besides, the more complete a reaction, the higher accuracy it achieves. The complete reaction of ribavirin and $\mathrm{H}_{2} \mathrm{O}_{2}$ has been found to occur at 10 min. Due to time constraints and the fact that $\mathrm{H}_{2} \mathrm{O}_{2}$ may decompose under long exposure, we select the $10 \mathrm{~min}$ incubation time for the experiment.

Optimization of incubation temperature: Curve A shows the effect of temperature on the absorption of ribavirin. From Fig. 16 we can see that higher incubation temperature leads to lower absorbance. There were two possible reasons: First, the reaction between ribavirin and $\mathrm{H}_{2} \mathrm{O}_{2}$ tended to complete as incubation temperature increased; Second, $\mathrm{H}_{2} \mathrm{O}_{2}$ decomposed as incubation temperature increased. Curve $\mathrm{B}$ shows the effect of incubation temperature on absorbance of $\mathrm{H}_{2} \mathrm{O}_{2}$ oxidation substrate. From Curve $\mathrm{B}$ we can see that the coloration of $\mathrm{H}_{2} \mathrm{O}_{2}$ was most visible at $35^{\circ} \mathrm{C}$. There were two possible explanations: either at $35^{\circ} \mathrm{C}$ the $\mathrm{H}_{2} \mathrm{O}_{2}$ oxidation substrate tended to complete, resulting in most obvious coloration, or at $35^{\circ} \mathrm{C}$ the reaction between $\mathrm{H}_{2} \mathrm{O}_{2}$ and ribavirin was incomplete, and the remaining $\mathrm{H}_{2} \mathrm{O}_{2}$ oxidized more 


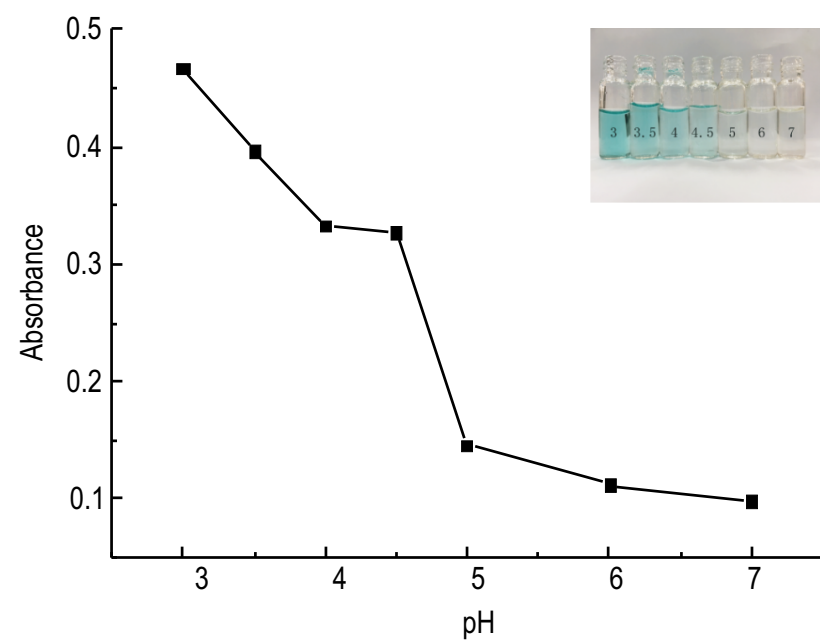

Fig. 14 : Effect of buffer solution pH on the system.

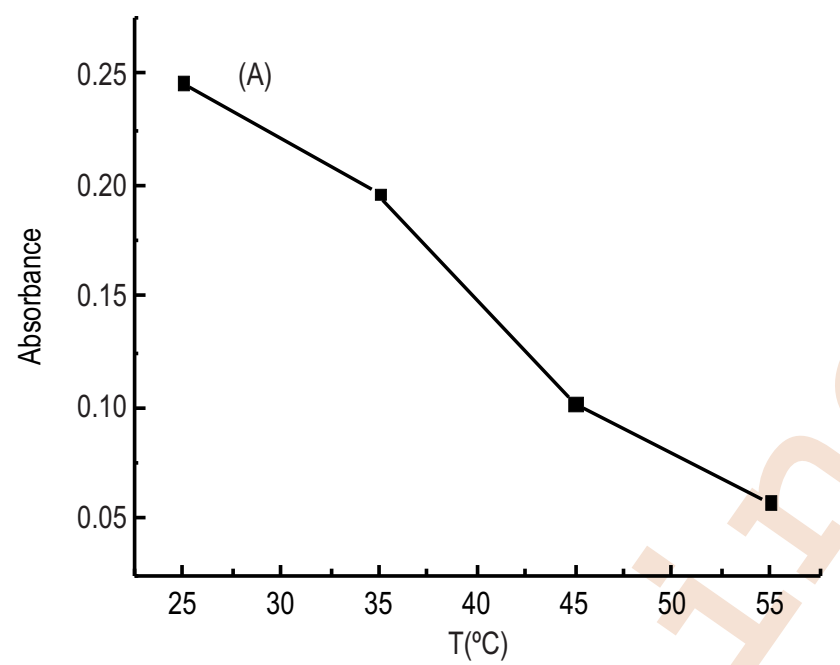

Fig. 16 : Optimization of incubation temperature $(A)$ and $\mathrm{H}_{2} \mathrm{O}_{2}$ coloration (B).

substrate and developed color. Based on observation from Curve $A$ and Curve $B$, the difference reached maximum at $35^{\circ} \mathrm{C}$, indicating that the reaction of ribavirin and $\mathrm{H}_{2} \mathrm{O}_{2}$ was most complete and decomposition of $\mathrm{H}_{2} \mathrm{O}_{2}$ was not significant. Therefore, the incubation temperature of $35^{\circ} \mathrm{C}$ was selected for incubation and coloration processes.

Detection of ribavirin: Linear equation and detection limit: A straight-line equation was drawn for standard concentration of ribavirin solution in water samples (X-axis) and absorbance ( $\mathrm{Y}$ axis), which showed a good linearity in between $1 \times 10^{-4} \mathrm{~mol}^{-1}$ $\sim 1 \times 10^{-6} \mathrm{~mol} \mathrm{I}^{-1}$. The linear equation was $\mathrm{y}=-1160.3 \mathrm{x}+0.1517$, and the detection limit was $2 \times 10^{-7} \mathrm{moll}^{-1}$.

The standard ribavirin solution of $2 \mu \mathrm{mol} \mathrm{I}^{-1}, 5 \mu \mathrm{mol} \mathrm{I}^{-1}, 8$ $\mu \mathrm{mol} \mathrm{I}^{-1}, 20 \mathrm{\mu mol} \mathrm{I}^{-1}$ and $80 \mathrm{mmol} \mathrm{I}^{-1}$ were prepared respectively, with blank feed samples obtained after treatment. In the

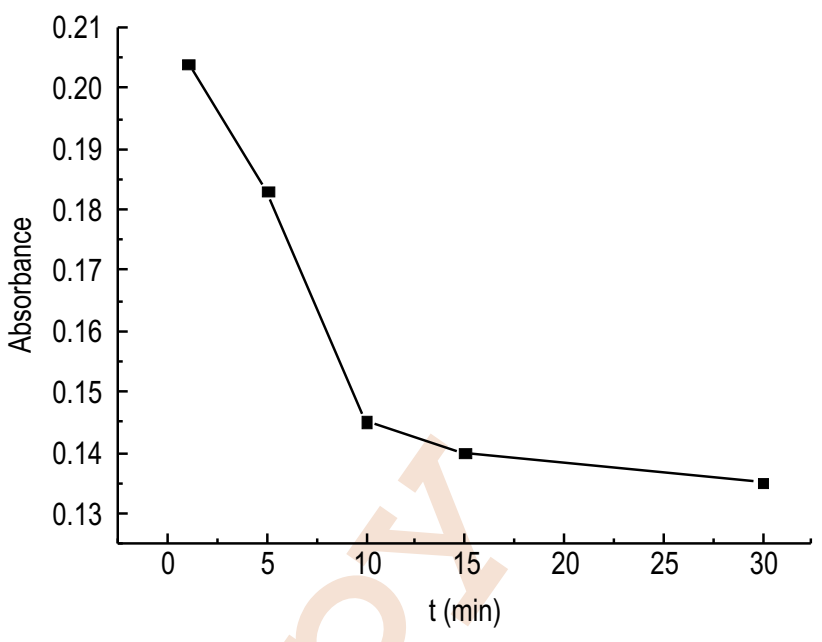

Fig. 15 : Effect of incubation time on the absorbance.

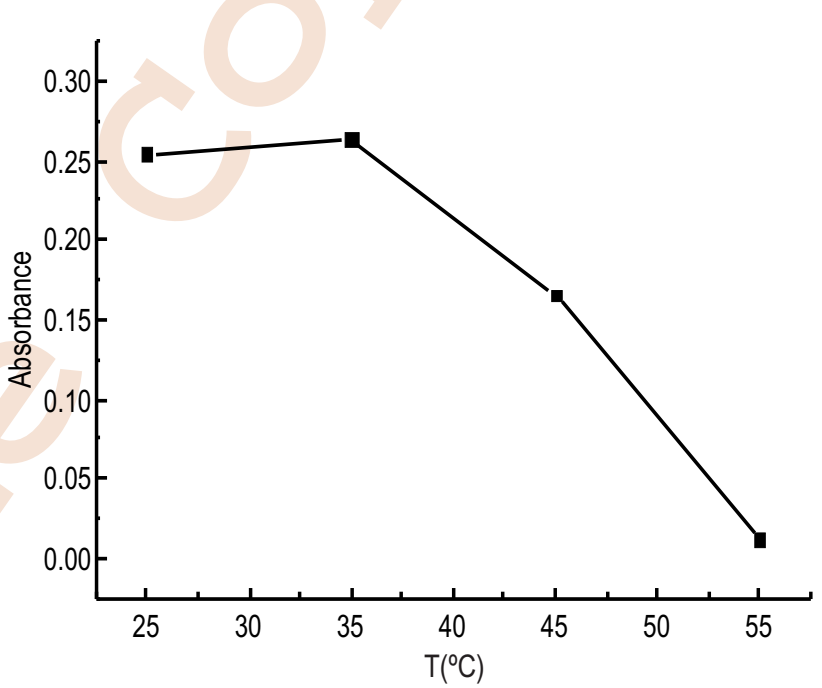

experiment, $10 \mathrm{mg}$ of $\mathrm{Fe}_{3} \mathrm{O}_{4} @ \mathrm{Fe}-\mathrm{ASB}$ and $5 \times 10^{-4} \mathrm{moll}^{-1} \mathrm{H}_{2} \mathrm{O}_{2}$ were used. A standard curve was drawn for standard ribavirin solution concentration in blank feed samples ( $\mathrm{X}$-axis) and absorbance ( $\mathrm{Y}$ axis), which showed a good linearity between $1 \times 10^{-4} \mathrm{moll}^{-1} \sim 1 \times 10^{-6}$ $\mathrm{mol} \mathrm{L}^{-1}$. The linear equation was $y=-4283.9 x+0.3659$, and the detection limit was $2 \times 10^{-7} \mathrm{moll}^{-1}$.

Precision and accuracy: The water and feed samples in the experiment were determined after simple pretreatment. Three ribavirin solutions with different concentration were used to conduct an additional experiment, which was repeated for three times to obtain the recovery rate and standard error (Gao et al., 2007; Tunggolou and Payus, 2017). This is to evaluate the accuracy and precision of the method. In the experiment, the blank treatment solution was used as matrix to eliminate interference. The results are shown in Table 2 . The recovery rate was about $92.0 \%$ 109 \% with standard error at $1.1 \%$ 3.1 \%, 


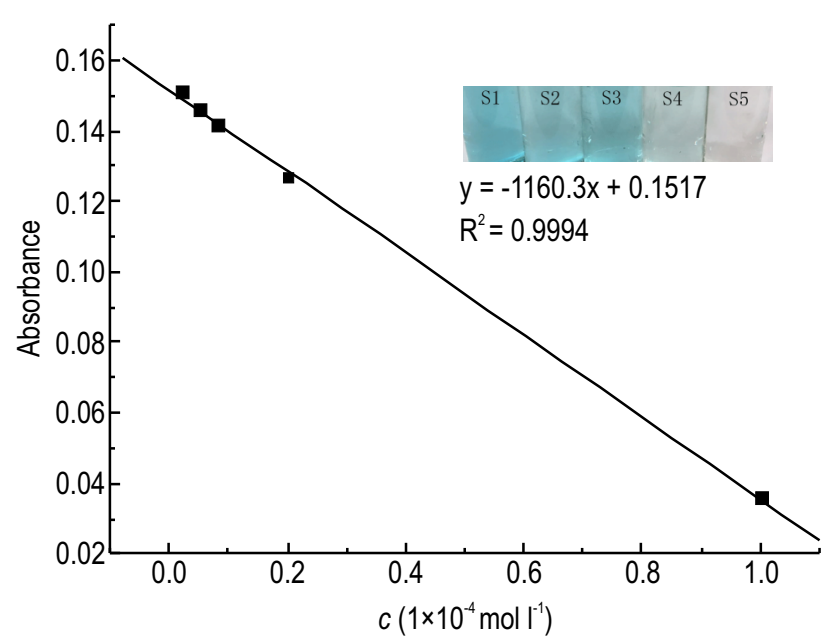

Fig. 17: Standard curve for determination of ribavirin in water samples 2 $\mu \mathrm{moll}^{-1}(\mathrm{~S} 1) ; 5 \mathrm{~mol} \mathrm{I}^{-1}(\mathrm{~S} 2) ; 8 \mathrm{mmol}^{-1}(\mathrm{~S} 3) ; 20 \mathrm{umol}^{-1}(\mathrm{~S} 4) ; 100 \mu \mathrm{mol} \mathrm{I}^{-1}$ (S5).

showing that the method had high accuracy and precision (Table 2).

Based on UV spectrophotometry, a method for indirect measure of ribavirin in water samples via $\mathrm{H}_{2} \mathrm{O}_{2}$ oxidation of substrate was designed. It was successfully used for the determination of ribavirin in feed samples and showed the character of stability, accuracy and precision. In this paper, a new Schiff base that can strongly coordinate with metals was synthesized. It was used as ligand to form a new magnetic metalorganic framework $\mathrm{Fe}_{3} \mathrm{O}_{4} @ \mathrm{Fe}-\mathrm{ASB}$, together with nano- $\mathrm{Fe}_{3} \mathrm{O}_{4}$, as metal center. The $\mathrm{Fe}_{3} \mathrm{O}_{4} @ \mathrm{Fe}$-ASB has good affinity to substrates and shows catalytic property. Due to its magnetic core structure, it shows good, stability and strong catalytic activity in the catalytic process. In future, it can be produced in large scale and applied to a wide range of analytical samples. The pretreatment method used in the experiment is simple, non-toxic, and can be carried out at room temperature without the need for large-scale instruments, indicating the broader potential of applications for the method in monitoring, quality control and sample analysis.

In this paper, a new Schiff base that can strongly coordinate with metals was synthesized. It was used as the ligand to form a new magnetic metal-organic framework Fe304@FeASB, together with nano-Fe304, as the metal center. The Fe304@Fe-ASB has good affinity to substrates and shows catalytic property. The Fe304@Fe-ASB was successfully used for the detection of ribavirin in water samples as catalytic material. It showed good stability, accuracy and precision.

\section{Acknowledgments}

This work is financially supported by the fund of Guangxi Key Laboratory of Green Processing of Sugar Resources (GXTZY201701), the fund of Key Laboratory for Processing of

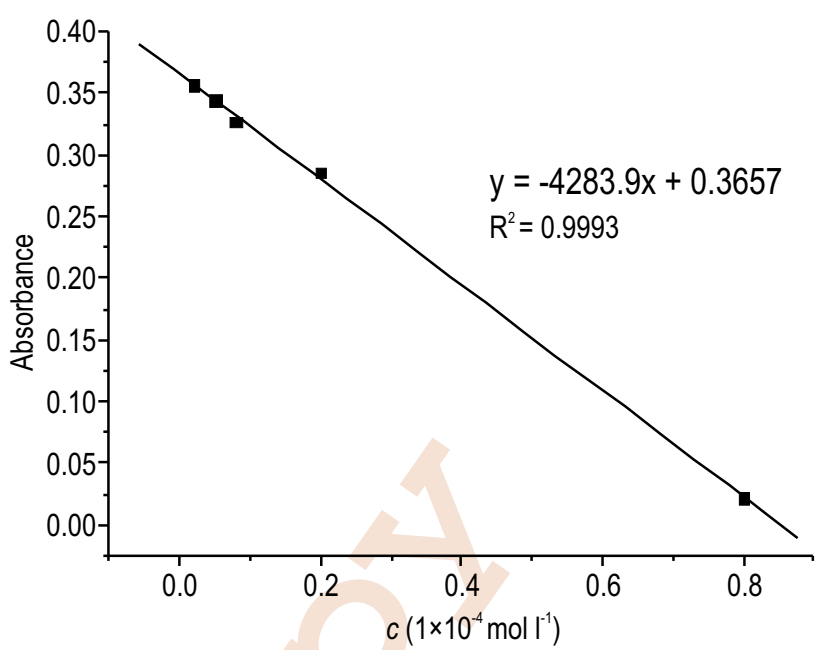

Fig. 18 : Standard curve for detection of ribavirin in feed samples $2 \mu \mathrm{mol}$ $\mathrm{I}^{-1}(\mathrm{~S} 1) ; 5 \mathrm{moll}^{-1}$ (S2); $8 \mu \mathrm{moll}^{-1}$ (S3); $20 \mu \mathrm{moll}^{-1}$ (S4); $80 \mathrm{moll}^{-1}$ (S5).

Sugar Resources of Guangxi Higher Education Institutes (2016TZYKF01) and high levels of innovation team and excellence Scholars Program in colleges of GuangXi.

\section{References}

Ashik, B.K., J. Shrestha and R. Subedi: Grain yield and yield attributing traits of maize genotypes under different planting dates. Malays. J. Sustain. Agric., 2, 06-08 (2018).

Ayaz, T., A.M. Khattak and N. Ahmad: Supra Soft R-Separation Axioms. Acta Sci. Malays., 2, 27-31(2018).

Azizan, N.H., Z.A.Z. Abidin and I.C. Phang: Study of cucumber mosaic virus gene expression in Capsicum annuum. Sci. Herit. J., 1, 29-31 (2017).

Basheer, A.O., M.M. Hanafiah and M.J. Abdulhasan: A study on water quality from Langat River, Selangor. Acta Sci. Malays., 1, 01-04 (2017).

Biswas, J.K.: A few words on black rice. Malays. J. Halal Res., 1, 01-02 (2018).

Chidumayo, E.: Seed scarification reduces seedling survival and tree growth and longevity in Senegalia polyacantha at a site in Central Zambia, Southern Africa. Malays. J. Sustain. Agric., 2, 19-23 (2018).

Cho, T.: Innovative Micro-Dust Reduction Technologies. Acta Chem. Malay., 1, 04-07 (2017).

Dong, W., X. Liu and W. Shi: Metal-organic framework MIL-53(Fe): Facile microwave-assisted synthesis and use as a highly active peroxidase mimetic for glucose biosensing. RSC Advan., 5, 17451-17457(2015).

Donglan, G.: Preparation of amino-functionalized magnetic materials and their adsorption properties for heavy metal ions in water. Jiangsu: Nanjing University of Science and Technology (2013).

Elmnifi, M., M. Alshelmany, M. Alhammaly and O. Imrayed: Energy recovery from municipal solid waste incinerati on Benghazi - Case Study. Eng. Herit. J., 2, 19-23(2018).

Fahim, N.F. and Z.S. Sathi: Assesment of hepatoprotective activity of roots and barks of achyranthes aspera in carbon tetrachloride- 
induced hepatotoxicity in rats. Malays. J. Halal Res., 1, 23-26 (2018).

Fei, K.: Study on the controllable preparation and catalytic performance of the metal-organic framework catalytic materials with a coreshell structure. Beijing: University of Science and Technology of China (2014).

Fei, W. and D. Li: Study on the bioequivalence of ribavirin granules by LCMS. Medical Information, 8, 3532-3533 (2011).

Gao, Q., J. Zhang, G. Hong and J. NI: Solvothermal synthesis of the magnetite sicro-nano sarticles $\left(\mathrm{Fe}_{3} \mathrm{O}_{4}\right)$ with sifferent sorphologies. Che. J. Chi. Uni., 32, 552-559 (2011).

Gao, L., J. Zhuang and L. Nie: Intrinsic peroxidase-like activity of ferromagnetic nanoparticles. Nature Nanotechnol., 26, 577-583 (2007).

Haijun, Z., W. Huafang and K. Deyu: Kinetic experiment on oxidation of different substrates by hydrogen peroxide with HRP as a catalyst. Henan: Henan University of Technology (2007).

Hua, W., W. Tao and Z. Siyan: Safety and benefit-risk analysis of ribavirin. Chin. J. Pharma., 15, 210-213(2006).

Ismail, H. and M.M. Hanafiah: Management of end-of-life electrical and electronic products: The challenges and the potential solutions for management enhancement in developing countries context. Acta Sci. Malays., 1, 05-08 (2017).

Jamal, F., A.M. Khattak, G.A. Khan and S. Abdullah: Five separation axioms in quad soft non-linear structure. Acta Sci. Malays., 2, 1420 (2018).

Jingxian, L., D. Bailin and W. Lina: A brief discussion of ribavirin. Heilong. Med. Phar., 36, 24-27(2013).

Kai, L., W. Lina and L. Jianzhong: Determination of ribavirin in feed and chicken by ultrahigh performance liquid chromatography-tandem mass spectrometry. Mod. J. Ani. Husb. Veter. Med., 5, 15-19 (2014).

Kang, L.: Study on the synthesis, structure and properties of metalorganic framework compounds constructed by nitrogencontaining ligands. Jilin: Jilin University, 86-89 (2015).

Lei, S., L. Dan and B. Yanfeng: Research progress on toxicity and residue detection methods of antiviral drugs. Chin. J. Veter. Drug., 47, 57-61(2013).

Mingrong, Z:: Synthesis, structure and biological activity of Schiff base metal complexes with enzyme inhibitors. Yunnan: Yunnan
University, pp. 108-112(2013).

Nawaz, A., F. Arshad and F. Khurshid: Evaluation of low-cost environment friendly natural extracts for the purification of drinking water. Earth Sci. Pak., 2, 23-25 (2018).

Qingyuan, L., J. Shengfu and H. Zhimou: Metal-organic frameworks and their applications in catalytic reactions. Progr. Chem., 24, 1506$1518(2012)$

Shaikh, M.M., A.O. AlSuhaimi, M.M. Hanafiah, M.A. Ashraf, A. Fantoukh and E. AlHarbi: Leachable volatile organic compounds from polyethylene plumbing plastic pipes: A case study of Medina Al Munawarah, SaudiArabia. Acta Chem. Malay., 1, $01-03$ (2017).

Shuai, Y.: Synthesis, characterization, analysis and application of mercap to Schiff base and its transition metal complexes. Guangxi: Guilin University of Technology, pp. 133-136 (2013).

Tunggolou, J. and C. Payus: Moringa oleifera as coagulant used in water purification process for consumption. Earth Sci. Pak., 1, 1-3 (2017).

Wahab, W.A. and A.N. Adzmi: The investigation of cytotoxic effect of Cinnamomum zeylanicum extracts on human breast cancer cell line (Mcf-7). Sci. Herit. J., 1, 23-28 (2017).

Wanzhen, L., L. Yi and R. Bin: Detection of ribavirin buccal tablets by UV spectrophotometry. Tianjin Pharmacy, 2, 29-30 (2005).

Wenying, Y.: Application and prospect of ribavirin. Asia-Pacific Traditional Medicine, 6, 175-177 (2010).

Xiaozhen, H.: Detection of ribavirin tablets by UV spectrophotometry and high-performance liquid chromatography. Chinese Comm. Doctors Med. Speci., 24, 6-7(2011).

Xiufang, $X .:$ Nano analog enzyme and its analytical application. Jiangsu: Jiangnan University, pp. 56-61 (2014).

Xu, D.: Research on The cultural construction of Homelink Real Estate. Eng. Herit. J., 2, 24-26 (2018)

Yang, H., Y. Xiong and P. Zhang: Colorimetric detection of mercury ions using $\mathrm{MnO}_{2}$ nanorods as enzyme mimics. Anal. Methods., 7 , 4596-4601 (2015).

Yang, H., Y. Xiong and P. Zhang: Colorimetric detection of mercury ions using $\mathrm{MnO}_{2}$ nanorods as enzyme mimics. Anal. Methods., 7 , 4596-4601 (2015).

Yingya, L., Z. Jian and Z. Julan: Hydrogen storage properties of nickel supported metal-organic framework compounds under mild conditions. Chin. J. Catalysis, 29, 655-659 (2008). 